\title{
Storage Behavior Study on Cactus Pear (Opuntia Ficus-Indica L.) \&Sustainable Utilization
}

\author{
Seblework Belaineh* \\ Ethiopian Biodiversity Institute, Addis Ababa, Ethiopia.
}

*Corresponding Author: Seblework Belaineh, Ethiopian Biodiversity Institute, Addis Ababa, Ethiopia.

\begin{abstract}
Cactus Pear (Opuntia ficus-indica L.) Belongs to family cacteaces. It is used as a staple fruit in Tgrayi region; it was introduced to the region by one priest more than hundred years ago. This crop is economically important endangered, and endemic to the region. So this plant belongs among the three EEE crops, propriety set to conserve seeds in the gene bank. This storage behavior study was conducted by the Ethiopian Biodiversity Institute (EBI) and collaboration with Adigrat University of Tigrayi region since 2016 Etc. Main purpose of this study was to categorize the storage behavior of Opuntia ficus-indica L. The plant is economically important, endangered, \& can be called also as endemic for the region (EEE). For EBI the main concern to study the storage behavior of this crop for long-term conservation and sustainable utilization of genetic resources in the country. It was not studied before to conserve in the gene-bank. Seeds initially collected from Tigrayi region of two localities, places near to Mekele called (siat-kuyet) and yeha at the border of Ttigrayi region. Locally they are called Garaoo \& Suluhuuna respectively. Initial viability test was done by using Tetrazolium solution (TZ) at different concentrations. All seeds were checked \& all are viable using the standard protocol method of seed storage behavior identification of IPGR. Seeds were dried at room temperature initial moisture content was measured \& was $8.5 \%$, then seeds were dried at room temperature up to $3.5 \%$ moisture content, after six months under -10oc, viability was tested again viability was $100 \%$ viable. We recommend both types of seeds can be kept as an orthodox seed, in the gene bank for long-term conservation and sustainable utilization.
\end{abstract}

Keywords: Storage behavior, Opuntia ficus-indica (Cactaceae) long-term conservation.

\section{INTRODUCTION}

\section{Cactus Pear (Opuntia ficus-indica L.) l.}

Cactus Pear Opuntia ficus-indica (L.) Milis used in different ways. Mainly as fruit, juice, \& even as salad mixture in Tigrayi region. leaves of this plant is used as main fodder source for any house hold animals, including to milking cows Cactus is originated from central and southern Mexico ${ }^{1}$ ). There are different reports with the introduction of cactus pear to Tigray. According to some legends cactus pear locally known as "beles" was introduced between 1848 and 1870 by Catholic Missionaries to eastern zone of Tigray, a priest called "Abune Yakob" who visited Erob, northern part of Tigray according to $\left({ }^{2}\right)$. As a result, the priest brought three spineless cladodes from Mexico, its country of origin and planted one cladode in Alitena (Erob), the second cladode planted in Golea (Gantaafeshum) and the third cladode planted in Lehe (Eritrea). In modern times, first and foremost, $\boldsymbol{O}$. ficus-indica is grown for the large, sweet fruits (often called "tunas"), which are available in local and commercial markets worldwide (3). Important tuna-growing regions include Mexico, Sicily, Algeria, Chile, Brazil, and northern Africa. In addition, the young cladodes (stem segments) of $\boldsymbol{O}$. ficus-indica are harvested as a vegetable crop (often called nopalitos). Although this crop is less valuable worldwide than the fruit crop \& vegetable products. Over the last few decades' interest in cactus pear as food and feed has increased due to its drought resistance, high biomass yield, high palatability and tolerance to salinity $\left(^{4}\right)$. Cactus pear cladodes are used to feed livestock $\left({ }^{5}\right)$. These plants have high biomass yields and are palatable, tolerant to salinity and have high digestible energy content. Opuntia has high water content [about $150 \mathrm{~g}$ dry matter (DM)/kg fresh material] and also serves as a source of water for livestock in dry regions described cactus pear as a miracle plant, dromedary of the vegetation world, and the bank of life as it can contribute to livelihoods of rural populations in dry seasons of some areas, assume greater agricultural importance in dry areas. $\left({ }^{6}\right.$ since 
a larger part of the land is destined to become arid or semi-arid due to climate change. Among the many biological pests, Cochineal is newly introduced biological pest and explosively expanding from the southern part of Tigray to the remaining part of the region. Critical reason for the crop conservation at this time Beles plant is highly endangered, because of this pest. The institute set priority to recognize the long-term storage behavior of seed, for long-term conservation, sustainable utilization, access \& benefit sharing for the local community. $\left({ }^{7}\right)$ Challenges of cactus pear in North Ethiopia, and in Tigrayi region, Particularly the northern part is endowed with wide plantation of cactus pear and the people of the area directly or indirectly depends on its wide range of products like food, feed and soil conservation and traditional medicines; this crucial fruit plant is given little attention in its research and improvements.

Although cactus pear is an integral plant for the economy of the people and also plays an important role in the environmental values in Tigray, the community is not on the right track in exploiting the potential of the tree. Surprisingly, the contribution that farmers are currently gaining from cactus is with zero cultivation practice. The agronomic techniques (harvesting, transporting and storing) are very traditional On top of this, there could be a probability that this plant could be a weed in the future unless proper management is practiced. Other than the improper cultivation and interventions, cactus has multiple newly introduced and old biological pests. Among the many biological pests, Cocheneal is newly introduced biological pest and explosively expanding from the southern part of Tigray to the remaining part of the region. Generally, cactus pear (Beles) is important for the livelihood of Tigray people\& feed for wildlife \& domestic animals too. In other ways as one of income generating sources of income, direct consumption and soil and water conservation. However, there are challenges like less attention of researchers and thus an availability of improved varieties of cactus pear and newly introduced pests like cochineal insects. Therefore, it is must to collect and improve the available germplasm of the crop, applying proper agronomic practices and controlling these pests. Author of this paper visited The holy land of Israel, have got the chance to see the productivity and its use at house hold level as fruit, salad with other vegetables ,juice, \& as marmalade. Has given a great attention in the use \& better production of this economically important for the community in all aspect of its nature.

\section{MATERIAL AND MeTHOD}

Two types of Beles local varieties were collected from Tegrai region (siat-kuyet near Mekele \& Erob yeha (district) by the local names are called Garoo \& suluhuna. These local varieties can be identified by the leaf types with spine and without spine. Collecting of well ripe and healthy fruit. Fruit collection from the tree was not an easy task. Most of the plantations are adjacent to each house hold or the neighboring up hills, even though all have owners nearby. Fruits were collected on altered times to process them independently. Seed viability test by using Tetrazolium solution (TZ) $1 \%$, and $0.1 \%$ by adjusting ph 7 . But commendably $1 \% \mathrm{TZ}$ solution was used. Seeds which cannot indicate a profound rose pigment are not viable. To check the viability of seeds after immersing them in the solution of TZ, kept them for 35 minutes under the incubator differently 220c at room temperature \& $300 \mathrm{c}$ in the incubator, all cleaned scarified and dry seeds show deep red color. They were kept under - 100c for six months. After six months' time again seed viability was first checked by Tetrazolium concentration $1 \%$ (TZ). All seeds display profound red color which expresses viability of all seeds. $(1 \mathrm{gmTZ} / 100 \mathrm{ml})$ was used for viability testing. Seed germination was slow on the first week and after 2 weeks show faster seed germination on both local varieties. Suluhunna shows faster germination response both at room temperature and under incubators also. On the first seed germination test without surface sterilization, almost all seeds were affected by fungus. After treating those by $7 \%$ ethanol for 10 minutes all seeds reply to growth performance $\&$ all seeds were clean.

\section{Methodology}

Collected, cleaned, dried seeds under room temperature undergo fumigation in the gene bank. Seed were separately washed by tap water, then surface sterilize $7 \%$ ethanol for 10 minutes at room temperature. Under aseptic condition seeds were scarified (remove cloves) of each seed under aseptic condition, which was a mind-numbing work, Cloves of each seeds were removed to accelerate germination. Surface sterilized by ethanol $7 \%$ for 2 minutes, washed by distilled water three times and put for germination test on filter papers on each petridishes 200 seeds blotted on filter paper. Blotter method was used for seed germination. Seed count for germinated seeds was documented from both local varieties first on the 7th day, then 15th day, and 21day last data was recorded on 35th days. All 
seeds show Very slow growth. But all perform development at room temperature and under the incubator too. All seeds show more than $85 \%$ growth performance earnings seeds are viable. For long term conservation seed kept by the rules of standard protocol of IPGR in the gene bank. All seeds were kept under -100 c for six month. After six months' all seeds were crisscross and tested for viability, all seeds show $100 \%$ viability, with slow response at different times.

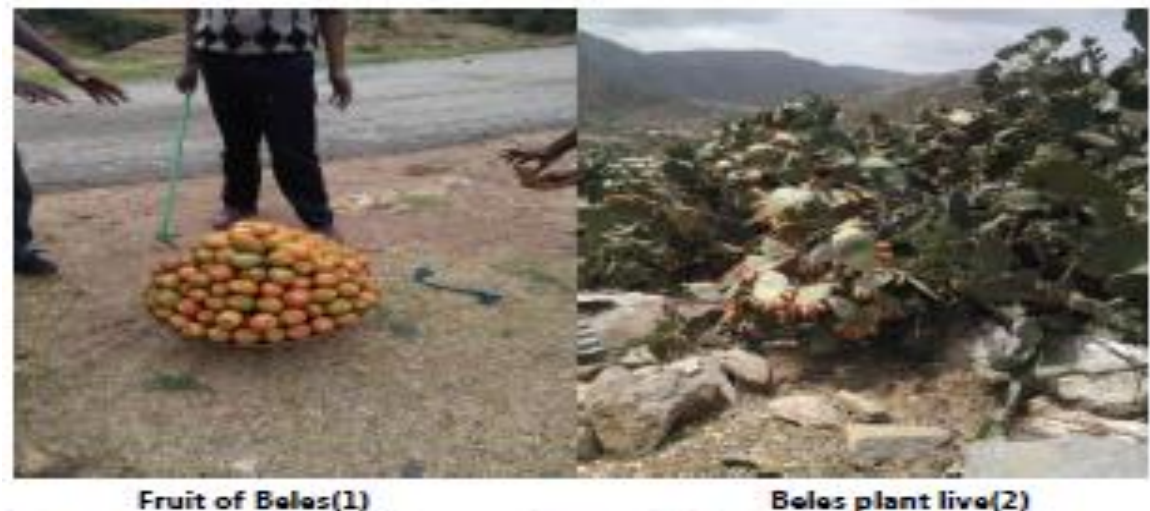

Fruit of Beles(1)

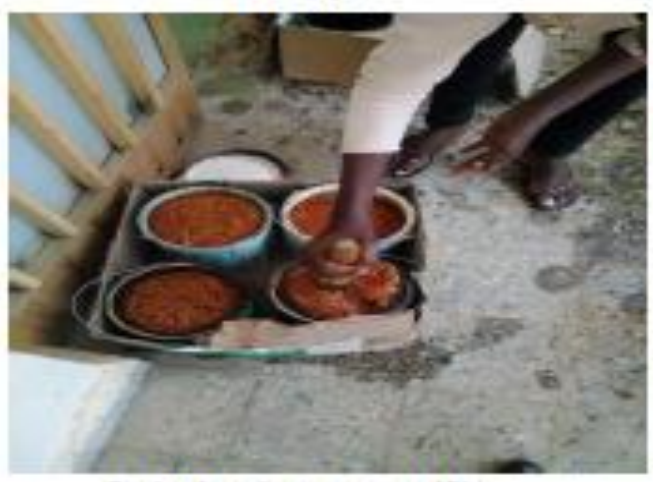

Fruit cleaning process (3)
Beles plant live(2)

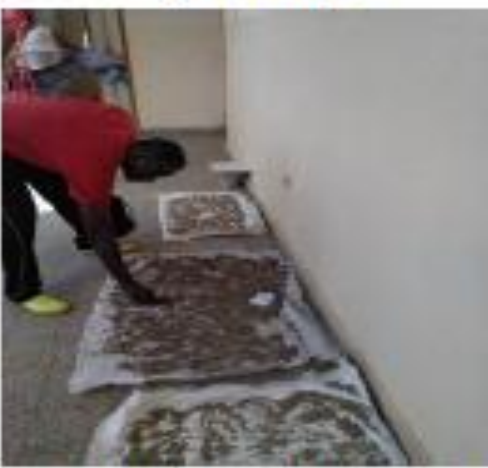

fruit drying atroom temperature(4)

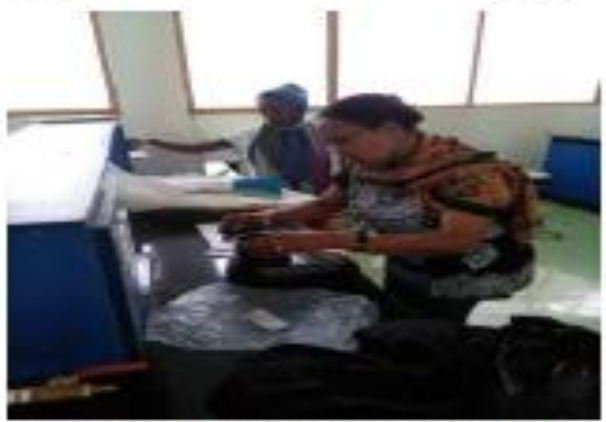

Initial Seed moisture testing(5)

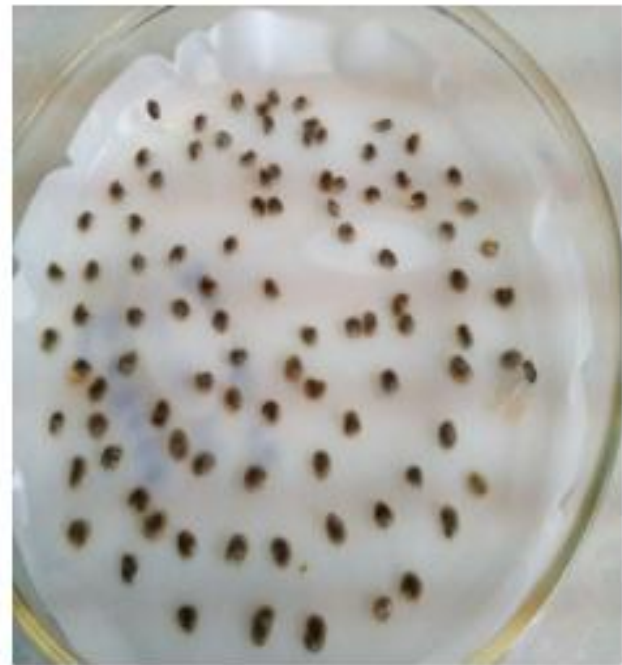

Al.garraoo growth progress

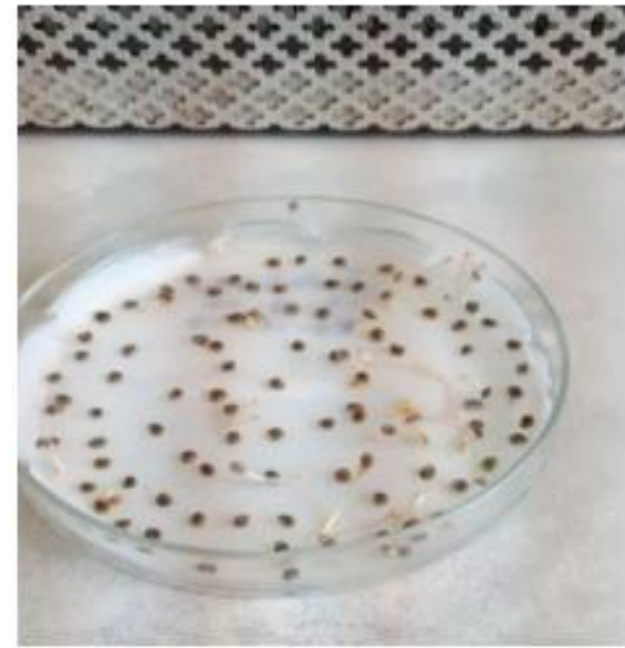

b2.suluuhuna growth progress 


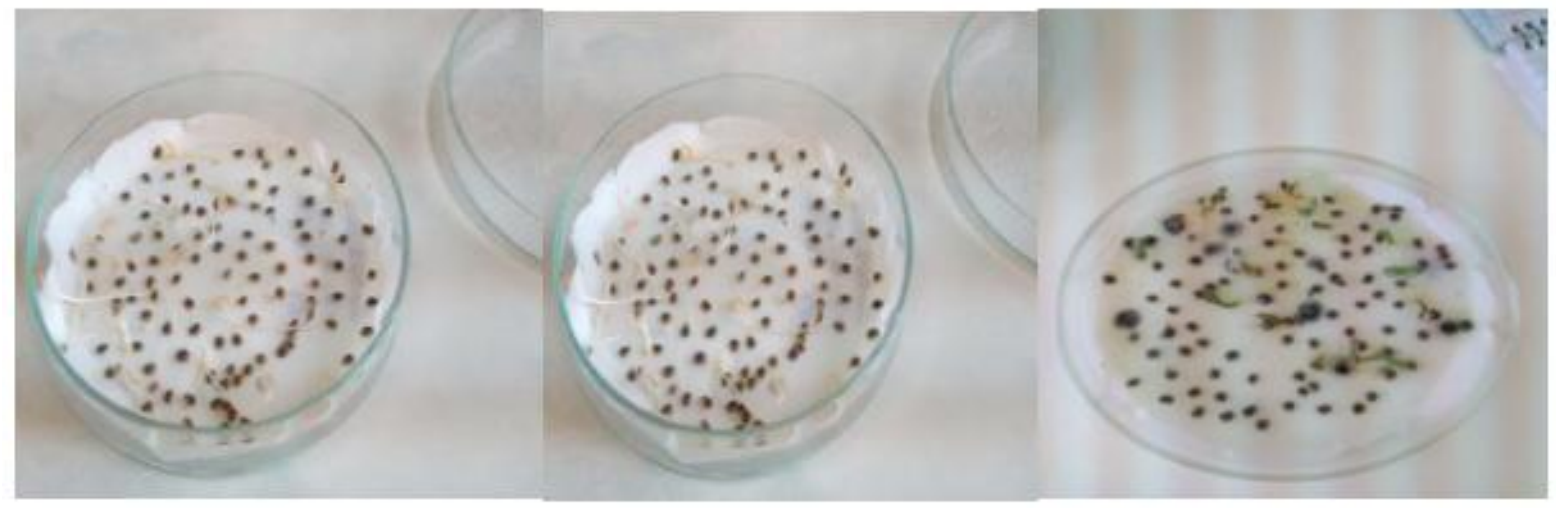

Seed germination progress

b2.suluhuuna

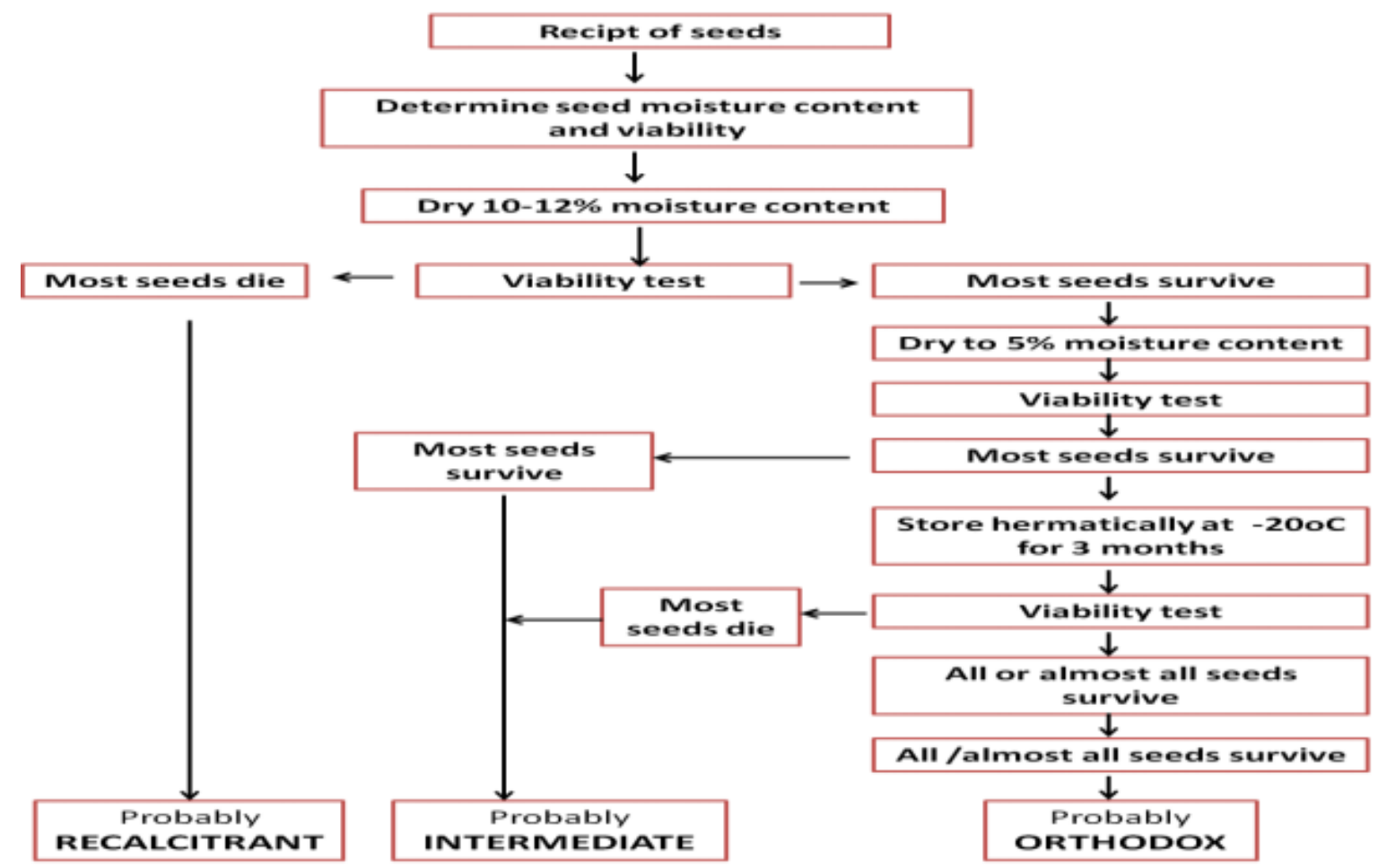

Table 1. Standard protocol for seed storage behavior determination was used to assess their storage behavior.

\section{RESULT \& DisCUSSION}

Opintus ficus ideica (cacteacea) is collected to localities very far one another, to study the storage behavior of seeds. Showed difference in all aspects starting from collection till draying and germination response. suluhuna is a local variety which was collected from the border of Tgryii region yehaa, has no spine on leaves and on the surface of fruits. But Goraoo which was collected from one district near to Mekele( kushet yahat) has spine both on leaves \& fruits. suluhunna show quick response on germination test and on viability test than garaoo. . Both can be used as fodder for animals, suluhuna can be used directly for animal feed without any treatment on red-hot fire, but Geraoo has to undergo some stapes to be free from this dangerous spine on a red-hot fire flame, according to the local community experience and endogenous knowledge. Fruits are deferent in size $\&$ test. suluhuna is bigger than Garaoo, more jucy than Garaoo. Suluuhuna is earning more price eye-catching than Garaoo. Generally, cactus pear (Beles) is important for the livelihood of Tigray people $\&$ feed for house hold animals during the dry seasons. As a supplementary beles is one of the leading income generating sources for women's in the community. Direct use for farmers it is zero tilling crop, highly drought resistant \& water consumption is very minimum, use full for local soil conservation, \& water conservation according to the local elderly farmers. However, there are challenges like less attention of researchers and thus an availability of improved varieties of cactus 
pear and newly introduced pests like cochineal insects. Therefore, it is a must to collect and improve as one of valuable plant germplasm of the crop. Applying proper agronomic practices and controlling these pests is considered as one way of endogenous mechanism of controlling this pest. This study indicated that the best possible way of conserving Opintus ficus ideica (cacteacea in the gene bank. This particular study shows that all the selected local varieties of Opintus ficus ideica (cacteacea) can be conserved for long- term conservation as one of the orthodox seeds under $-10^{0} \mathrm{c}$ in the gene bank..

\section{CONCLUSION}

Therefore, it is a must to collect and improve as one of valuable plant germplasm of the crop, applying proper agronomic practices and controlling these pests. This study indicated that the best possible way of conserving Opintus ficus ideica (cacteacea) in the gene bank. This particular study shows that all the selected local varieties of Opintus ficus ideica (cacteacea can be conserved for long term conservation as one of the orthodox seeds under $-10^{\circ} \mathrm{c}$.

\section{ACKNOWLEDGMENT}

This work was financially supported by EBI (Ethiopian biodiversity Institute) as one of our propriety storage behavioral studies. I thank Ato Abebe Gebremarkos for their field work assistance, last but not list w/ro Alemthehayi Girma for her assistance in laboratory work.

\section{REFERENCES}

[1] The origins of an important cactus crop, Opuntia ficus-indica (Cactaceae): new molecular evidence ${ }^{1} \mathrm{M}$. Patrick Griffith, First published: 01 November 2004

[2] Cactus Pear (Opuntia ficus-indica L.) in Tigray, North Ethiopia: History, potential and challenges (Review paper) Shushay welderufael abrha Department of plant science, Adigrat University, Adigrat, Ethiopia, p.o.box,50 Email address: shushay24@gmail.comJournal of Biology, Agriculture and Healthcare www.iiste.org ISSN 2224-3208 (Paper) ISSN 2225-093X (Online) Vol.4, No.25, 201

[3] The cactus (Opuntia ficus indica) is expanding throughout Southern Tigray, Northern. Ethiopia. ...... As reported by Barbara (1995), cactus plays an ecological role in soil and water conservation for arid and semi ...... Similarly, previous studies by RVDP (1996) reported that the soil type ...... Nefzaoui, A. and Ben Salem. (2002).

[4] South African Journal of Animal Science 2010, 40 (Issue 5, Supplement 1) () South African Society for Animal Science Peer-reviewed paper: Proc. 43rd Congress of the South African Society for Animal Science.

[5] Effects of sun-dried Opuntia ficus-indica on feed and water intake and excretion of urine and faeces by Dorper sheep C.M.D. da C. Menezes1\#, L.M.J. Schwalbach2, W.J. Combrinck2, M.D. Fair2 and H.O. de Waal2.

[6] Felker, P., lnglese, P., 2003. Short-term and long-term research needs for Opuntia Jicus-indica (L.) Mill, utilisation in arid areas. J. Prof. Ass. Cactus Dev. pp. 131-145.

[7] Cactus stems (Opuntia spp.): A review on their chemistry, technology .2005; Stintzing \& Carle 2005; ElSamahy et al. .... can be produced in alley-cropping system is considered an excellent diet for sheep (Ben Salem et al., 2010)

[8] CACTUS PEAR (Opuntia ficus-indica L): A FUTURE ASSET FOR SUSTAINABILITY OF DRYLANDS IN NORTHERN ETHIOPIA Solomon Abera Bariagabre1*, Isaack K. Asante2, Christopher Gordon1 and Ted Yemoh Ananng1 1 Institute for Environment and Sanitation Studies, University of Ghana, Legon, Accra 2Department of Botany, University of Ghana, Legon, Accra P.O. Box LG 209, Legon, Accra, Ghana E-mail: bariagabre@yahoo.co.uk (*Corresponding Author). International Journal of Science, Environment ISSN 2278-3687 (O) and Technology, Vol. 5, No 3, 2016, 846 - 860

Citation: Seblework Belaineh " Storage Behavior Study on Cactus Pear (Opuntia Ficus-Indica L.) \&Sustainable Utilization", International Journal of Forestry and Horticulture (IJFH), vol. 5, no. 4, pp. 36-40, 2019. Available: DOI: http://dx.doi.org/ 10.20431/2454-9428.0504004

Copyright: (๑) 2019 Authors. This is an open-access article distributed under the terms of the Creative Commons Attribution License, which permits unrestricted use, distribution, and reproduction in any medium, provided the original author and source are credited. 